\title{
STRUČNO USAVRŠAVANJE KNJIŽNIČARA KNJIŽNIČNOG SUSTAVA SVEUČILIŠTA U RIJECI
}

\author{
PROFESSSIONAL TRAINING/ CONTINUING \\ EDUCATION OF LIBRARIANS WITHIN THE UNIVERSITY \\ OF RIJEKA LIBRARY NETWORK
}

\section{Sanja Heberling Dragičević}

Sveučilišna knjižnica Rijeka, Sveučilište u Rijeci

shdragicevic@svkri.hr

\section{Sanja Kosić}

Sveučilišna knjižnica Rijeka, Sveučilište u Rijeci skosic@svkri.hr

UDK / UDC 023:377(497.5 Rijeka)

Izvorni znanstveni rad / Original scientific paper

Priljeno / Received: 3. 11. 2018.

Prihvaćeno / Accepted: 11. 12. 2018.

\section{Sažetak}

Cilj. Cilj je rada prikazati opću sliku stanja stručnog usavršavanja knjižničarskog osoblja stalno zaposlenog u knjižnicama sastavnica Sveučilišta u Rijeci, a koje zajedno čine Sveučilišni riječki knjižnični sustav (SveRiKS). Nastoje se utvrditi problemi u realizaciji stručnog usavršavanja te mogućnosti njihova prevladavanja u ovkiru SveRiKS-a, kao i potrebe stručnog usavršavanja u budućnosti.

Pristup/metodologija/dizajn. Na temelju podataka o realiziranim programima cjeloživotnog učenja namijenjenim knjižničarskom osoblju SveRiKS-a u razdoblju 2013.-2017. provedeno je anketno ispitivanje kako bi se utvrdili stavovi i mišljenja samih knjižničara o stručnom usavršavanju u promatranom razdoblju, preprekama na koje nailaze te potrebama i poželjnom načinu realizacije u budućnosti.

Rezultati. Rezultati istraživanja pokazuju da se programi stručnog usavršavanja knjižničarskog osoblja SveRiKS-a provode redovito, a sadržaji edukacija u skladu su s

Vjesnik bibliotekara Hrvatske 61, 2(2018), 305-324

ISSN 0507-1925

(C) VBH 2018. 
promjenama i zahtjevima okruženja. Knjižničarsko osoblje kontinuirano se stručno usavršava te jasno procjenjuje probleme i svoje potrebe u kontekstu cjeloživotnog učenja. Podaci ukazuju na to da temeljne knjižničarske kompetencije više nisu dovoljne za poslove koji se obavljaju, a kraće edukacije s temama izravno primjenjivim na konkretne poslove pokazuju se kao jedno od rješenja.

Originalnost/vrijednost. Provedeno istraživanje za Sveučilišnu knjižnicu Rijeka predstavlja polazište u promišljanju programa stručnog usavršavanja za knjižničarsko osoblje knjižničnog sustava Sveučilišta u Rijeci u narednom razdoblju, ali i za argumentirano zauzimanje stava prema osnivaču s ciljem njegova usustavljivanja.

Ključne riječi: cjeloživotno učenje, stalno stručno usavršavanje, Sveučilišni riječki knjižnični sustav

\begin{abstract}
Purpose. The purpose of this paper is to present the state of professional training and development (continuing education) of the librarians in the libraries of the University of Rijeka. Together, these libraries constitute the University of Rijeka's library network (SveRiKS). The paper aims to identify the problems in the realization of continuing education and professional development of librarians and find possibilities of their overcoming, and also to anticipate the librarians' needs in continuing education in future.
\end{abstract}

Approach/methodology/design. Based on the data on the realized programs of lifelong learning for librarians between 2013 and 2017, a survey was conducted in order to determine attitudes and opinions of librarians about professional training, obstacles they encounter, and their needs and preferred training methods in future.

Findings. The survey results show that the professional training programs for librarians in the University of Rijeka library network have been carried out regularly and the educational content was in accordance with the current trends, changes, and demands in the modern environment. The librarians are continually involved in the processes of professional training and are successful in evaluating problems and needs in the context of lifelong learning. The results also show that the basic librarians' competencies are no longer sufficient for a successful carrying out of their everyday tasks. The shorter trainings in the educational contents that are directly applicable in librarians' work are considered as a possible solution.

Originality value. For the University of Rijeka Library, the survey results present a starting point for an assessment of the current state and needs of the librarians, but also for a well-argued discussion with the libraries' founder, the University, in order to systematically develop a professional training plan for the library staff.

Keywords: lifelong learning, continuing education, University of Rijeka's library network 


\section{Uvod}

U svim djelatnostima, pa tako i u knjižničarstvu, posljednjih su se desetljeća dogodile brojne i iznimno velike promjene. Povezane su mahom s tehnološkim razvojem koji je potom uzrokovao promjene u svim slojevima i aktivnostima društva. Promjene se događaju tolikom brzinom da više nije dovoljno samo odgovarati na njih jednom kada se dogode, već ih je nužno predvidjeti i unaprijed ponuditi rješenje za izazove koji tek dolaze.

Knjižničarska zajednica uvijek iznova definira svoju ulogu u svijetu gdje je promjena stalna te nudi svoje usluge kao odgovore na nadolazeće izazove. Prepoznajući i podržavajući koncept održivog razvoja na svim poljima, zajednica se uključuje i u Program za održivi razvoj $2030^{1}$ Ujedinjenih naroda, nudeći svoje znanje, vještine i kompetencije za postizanje tim programom predviđenih ciljeva.

Kako bi uspješno svladavali nove zadaće, knjižničari moraju krenuti od sebe te se u kontekstu cjeloživotnog učenja kvalitetno obrazovati i kontinuirano stručno usavršavati.

Obrazovanje knjižničara već dulje zahvaćaju velike promjene, koje su vidljive i u sustavu formalnog obrazovanja. Snažan razvoj informacijske i komunikacijske tehnologije sredinom 20. stoljeća, kao i razvoj interneta, dovodi do novih načina stvaranja, pohrane i pretraživanja informacija, što pred knjižničare postavlja nove zahtjeve. ${ }^{2}$ Usporedo s razvojem informacijske i komunikacijske tehnologije, suvremeni studiji orijentirani su na „korisnike informacija, tehnologiju, pristup i informaciju“. ${ }^{3}$ No završetak formalnog obrazovanja za suvremene informacijske stručnjake nije kraj učenju.

Tijekom profesionalnog rada knjižničari se kontinuirano usavršavaju, odnosno uvijek iznova osposobljavaju da bi mogli pružiti kvalitetnu uslugu. ${ }^{4}$ Kontinuirana je edukacija nužnost i obveza ${ }^{5}$, a neformalni i informalni oblici obrazovanja temelj su daljnjeg profesionalnog napretka knjižničara, odnosno informacijskih stručnjaka.

\footnotetext{
1 Usp. Transforming our world: the 2030 agenda for sustainable development. [citirano: 201810-30]. Dostupno na: https://sustainabledevelopment.un.org/post2015/transformingourworld.

2 Usp. Erl Šafar, M.; T. Lubina. Formalno obrazovanje knjižničara: kratki povijesni pregled. // Vjesnik bibliotekara Hrvatske 61, 1(2018), str. 226. DOI: https://doi.org/10.30754/vbh.61.1.647.

3 Isto, str. 228.

4 Usp. Horvat, A. Cjeloživotno učenje knjižničara u Hrvatskoj: stanje i mogućnosti. // Cjeloživotno učenje knjižničara: ishodi učenja i fleksibilnost / urednice Aleksandra Horvat, Dijana Machala. Zagreb: Nacionalna i sveučilišna knjižnica, 2009. Str.26 [citirano: 2018-10-31]. Dostupno na: http://www.nsk.hr/cuk/cuk.pdf.

5 Usp. Lazzarich, L. Kontinuirana edukacija informacijskih stručnjaka (ili možete li dobiti posao). // Edukacija korisnika i knjižničnog osoblja / 5. dani specijalnog knjižničarstva Hrvatske, Opatija, 10. i 11. travnja 2003. Zagreb: Hrvatsko knjižničarsko društvo, 2004. Str. 72.
} 
Neformalno je obrazovanje organizirano, no provodi se izvan redovitog školskog sustava. ${ }^{6} \mathrm{U}$ taj oblik obrazovanja ubraja se i stalno stručno usavršavanje stručnjaka. U Hrvatskoj je sustavan pristup stalnom stručnom usavršavanju olakšan osnivanjem Centra za stalno stručno usavršavanje knjižničara (CSSU), koji provodi program trajne izobrazbe kroz jednodnevna predavanja, radionice i sl. ${ }^{7}$ Informalno obrazovanje stvar je pojedinca, to je samoobrazovanje, a naziva se i iskustvenim učenjem. ${ }^{8}$ Ti su oblici obrazovanja mnogo fleksibilniji od formalnog sustava i lakše se prilagođavaju promjenama i novim zahtjevima promjenjive okoline. Pristupanje tim oblicima obrazovanja individualna je odluka, ovisna o svijesti o potrebi nadgradnje postojećih znanja i vještina. Ipak, na odluku o dodatnoj edukaciji, osim vlastite volje, utječe i niz drugih čimbenika, poput dostupnosti, organizacijskih i financijskih mogućnosti pojedinca i institucije i sl. Stoga je pretpostavka sustavnom stalnom stručnom usavršavanju strateško promišljanje i shvaćanje njegove važnosti na razini sustava, a potom i osiguravanje uvjeta za njegovo provođenje.

Posljednjih godina u Hrvatskoj je veći broj autora pisao o stalnom stručnom usavršavanju knjižničara, odnosno o njihovu obrazovanju i potrebnim kompetencijama. Porast broja radova na tu temu još je jedan pokazatelj njezine važnosti za knjižničarsku zajednicu. Dijana Machala u monografiji Knjižničarske kompetencije: pogled na razvoj profesije ${ }^{9}$ daje detaljan povijesni pregled razvoja knjižničarskih kompetencija, pojašnjava kompetencijski pristup u knjižničarstvu te govori o načinima izobrazbe knjižničara. Knjiga Ksenije Švend-Radeljak ${ }^{10}$ donosi pregled obrazovanja i statusa knjižničara prije uvođenja studija bibliotekarstva u Hrvatskoj. U navedenom je razdoblju objavljena nekolicina članaka: Marija Erl Šafar i Tihana Lubina kroz pregledni rad govore o formalnom obrazovanju knjižničara i njegovim promjenama kroz povijest ${ }^{11}$, Tatjana Aparac-Jelušić osvrće se na obrazovanje knjižničara u

\footnotetext{
6 Usp. Machala, D. Knjižničarske kompetencije: pogled na razvoj profesije. Zagreb: Hrvatska sveučilišna naklada: Nacionalna i sveučilišna knjižnica, 2015. Str. 179.

7 Usp. Machala, D.; A. Horvat. Nacionalni program trajne izobrazbe knjižničara temeljen na ishodima učenja: prema priznavanju neformalnog obrazovanja knjižničara. // Cjeloživotno učenje knjižničara: ishodi učenja i fleksibilnost / urednice Aleksandra Horvat, Dijana Machala. Zagreb: Nacionalna i sveučilišna knjižnica, 2009. Str.152 [citirano: 2018-10-31]. Dostupno na: http:// www.nsk.hr/cuk/cuk.pdf.

8 Machala, D. Nav. dj., str. 199.

9 Isto.

10 Usp. Švenda-Radeljak, K. Obrazovanje i status knjižničara u Hrvatskoj do uvođenja studija bibliotekarstva. Zagreb : Pravni fakultet Sveučilišta u Zagrebu, 2018.

1 Erl Šafar, M.; T. Lubina. Nav. dj.
} 
eri digitalne knjižnice ${ }^{12}$, dok Ivana Ivančić Medved govori o razvoju karijere knjižničara. ${ }^{13}$

Nužnost edukacije knjižničara vidljiva je iz pregleda tema izlaganja svih stručnih skupova na kojima knjižničari sudjeluju, a gdje temeljni knjižničarski poslovi poput posudbe i katalogizacije nisu više najzastupljenije teme. ${ }^{14}$ Danas se mnogo više govori o komunikaciji, prezentaciji, pedagoškim i upravljačkim vještinama, mjerenju kvalitete, javnom zagovaranju i sl., a svaka od navedenih tema zahtijeva ulaganje dodatnog napora kako bi se određena vještina usvojila. Njihovo usvajanje i primjenu u svakodnevnom radu zahtijevaju i osnivači knjižnica, pa tako i Sveučilište u Rijeci.

\section{Stručno usavršavanje knjižničara ${ }^{15}$ knjižničnog sustava Sveučili- šta u Rijeci}

Sveučilište u Rijeci 2007. godine donijelo je Strategiju 2007.-2013. ${ }^{16}$ kojom najavljuje formiranje integriranog knjižničnog sustava Sveučilišta, što je značilo nove zadaće za knjižničare. Strateški dokumenti koji su slijedili pobliže su definirali sustav te nadograđivali zadaće knjižničarskog osoblja. Postalo je neophodno to da i knjižničari nauče strateški promišljati o sustavu čiji su dio te da usvoje upravljačke, komunikacijske i druge vještine koje nisu dio temeljnog obrazovanja knjižničara. Ispunjavanje zadaća nužnih za udovoljavanje zahtjevima osnivača učinilo je stručno usavršavanje nužnim za knjižničare. Uspostava Sveučilišnog riječkog knjižničnog sustava tu je potrebu samo dodatno naglasila.

12 Usp. Aparac-Jelušić, T. Obrazovanje za dogotalne knjižnice: pogled iz Europe. // Libellarium 9, 2(2016), 5-24. [citirano 2018-10-5]. Dostupno na: https://hrcak.srce.hr/index.php?show=clanak\&id_clanak_jezik=260470.

13 Usp. Ivančić Medved, I. Knjižničar i karijera. // Knjižničarstvo 17, 2(2013), 75-84. [citirano 2018-10-4]. Dostupno na: http://www.knjiznicarstvo.com.hr/2014/05/08/228-ivancic-medved/.

14 Pregledom skupova u području knjižničarstva koji su se održavali u promatranom razdoblju izdvajaju se teme suradnje knjižnice i okruženja, uloge knjižnica u provođenju agende UN 2030 i ciljeva održivog razvoja, nakladništva u baštinskim ustanovama i nakladništvu u digitalnom okruženju, vrednovanja knjižnica i javnog zagovaranja, informacija u medijskom prostoru, knjižničnih usluga za sve vrste korisnika s posebnim naglaskom na ranjivim skupinama, potom izlaganja o standardima u knjižničarstvu, zelenim knjižnicama, interoperabilnosti u arhivima, knjižnicama i muzejima i sl. Izvor: Hrvatsko knjižničarsko društvo. Skupovi u zemlji. Arhiva. [citirano 2018-11-27]. Dostupno na: http://hkdrustvo.hr/hr/skupovi/arhiva/u_zemlji/.

15 U ovom radu pojam „knjižničar“ koristi se kao sinonim za sve stručno knjižničarsko osoblje.

16 Strategija Sveučilišta u Rijeci 2007.-2013. [citirano: 2018-10-29]. Dostupno na: http://www. uniri.hr/files/staticki_dio/strategija/SVURI01-01Strategija.pdf. 


\subsection{Knjižnice u sustavu SveRiKS-a}

Sveučilišni riječki knjižnični sustav (u daljnjem tekstu: SveRiKS) podsustav je Sveučilišta u Rijeci koji se počeo razvijati 2010. g., nakon odluke Senata Sveučilišta o izgradnji integriranog knjižničnog sustava, sa svrhom ,jedinstvenog i usklađenog djelovanja radi provođenja strateških ciljeva Sveučilišta na području knjižnične djelatnosti“". ${ }^{17}$

Sustav SveRiKS čini 10 redovnih sastavnica, tj. knjižnica koje djeluju na Sveučilištu u Rijeci ${ }^{18}$ : Sveučilišna knjižnica Rijeka, Podružnica Sveučilišne knjižnice (djeluje kao fakultetska knjžnica jednog fakulteta i četiriju sveučilišnih odjela Učiteljskog fakulteta, Odjela za biotehnologiju, Odjela za fiziku, Odjela za informatiku i Odjela za matematiku) te osam fakultetskih knjižnica (Ekonomskog fakulteta, Fakulteta za menadžment u turizmu i ugostiteljstvu, Filozofskog fakulteta, Građevinskog fakulteta, Medicinskog fakulteta, Pomorskog fakulteta, Pravnog fakulteta i Tehničkog fakulteta).

Redovne sastavnice sustava imaju sveukupno 46 zaposlenika. Sveučilišna knjižnica Rijeka (s podružnicom) ima ukupno 28 stalno zaposlenih ${ }^{19}$, od toga 19 stručnih djelatnika prema postignutom knjižničarskom stručnom zvanju, uključujući ravnateljicu. Fakultetske knjižnice imaju ukupno 18 stalno zaposlenih stručnih djelatnika. U jednoj od knjižnica stalno je zaposlena samo jedna osoba, u pet njih po dvije osobe, a u ostale dvije knjižnice tri, odnosno četiri osobe.

U sustavu SveRiKS zaposleno je ukupno 37 stručnih knjižničarskih djelatnika koji se, prema jednoj od točaka misije sustava, trebaju cjeloživotno usavršavati u svrhu razvoja vlastitih kompetencija. Pritom važnu ulogu ima Sveučilišna knjižnica koja, kao matična knjižnica, pruža stručnu pomoć i vodi brigu o stručnom usavršavanju.

\subsection{Stalno stručno usavršavanje knjižničara SveRiKS-a}

Sveučilišna knjižnica Rijeka (SVKRI) svake godine izrađuje program stručne, znanstvene i obrazovne djelatnosti kojim se planiraju edukacije namijenjene knjižničarskom osoblju Sveučilišta u Rijeci. U nekim od planiranih programa SVKRI je i organizator i realizator sadržaja, a u većini organizira ili suorganizira programe. U (su)organizaciji programa stručnog usavršavanja za SveRiKS, Sveučilišna knjižnica Rijeka uglavnom surađuje s Centrom za stalno stručno usavr-

17 Sveučilišna knjižnica Rijeka. Knjižnični sustav sveučilišta. [citirano 2018-10-5]. Dostupno na: https://svkri.uniri.hr/index.php/knjiznicni-sustav-sveucilista/o-sustavu.

18 Sveučilišna knjižnica Rijeka. Knjižnični sustav sveučilišta u Rijeci. [citirano 2018-10-5]. Dostupno na: https://svkri.uniri.hr/index.php/knjiznicni-sustav-sveucilista/knjiznice.

19 Sveučilišna knjižnica Rijeka. O nama. [citirano 2018-10-5]. Dostupno na: https://svkri.uniri. hr/index.php/o-nama/djelatnici. 
šavanje Nacionalne i sveučilišne knjižnice u Zagrebu, odnosno s Nacionalnom i sveučilišnom knjižnicom u Zagrebu, Gradskom knjižnicom Rijeka, Sveučilišnim računskim centrom Sveučilišta u Zagrebu, Hrvatskim knjižničarskim društvom, Knjižničarskim društvom Rijeka itd.

Najčešći oblik edukacije jesu radionice, a teme se biraju na temelju iskazanih potreba knjižničara ili aktualnosti u okruženju. Analiza tema radionica održanih u posljednjih pet godina ${ }^{20}$ pokazuje da su se teme edukacija najčešće birale u skladu s promjenama i zahtjevima u sustavu i na Sveučilištu u Rijeci. Od 2013. godine do danas na odabir tema edukacija posebno su utjecali pojedini projekti i promjene kako u sustavu znanosti i visokog orbazovanja tako i izvan njega. Naznačajniji događaji i edukacijski sadržaji kojima su popraćeni jesu:

- projekt IRiKS, tj. integriranje računalne infrastrukture knjižničnog sustava Sveučilišta u Rijeci, osposobljavanje i rad u skupnom katalogu organiziran je niz radionica s temom kooperativne katalogizacije, predstavljeno je skraćeno izdanje Univerzalne decimalne klasifikcije i sl.

- nabava i implementacija Ebsco Discovery Servicea - organizirane su radionice o mogućnostima pretraživača te administriranju

- mjerenja i sustavi osiguravanja kvalitete - pored radionica i izlaganja u području prikupljanja statističkih podataka, Sveučilišna knjižnica organizirala je stručni skup Mjerenje kvalitete u hrvatskim knjižnicama

- uspostava repozitorija sastavnica i sveučilišnog repozitorija u Dabru organizirano je nekoliko edukacija, a knjižničari sustava SveRiKS i danas sudjeluju u radu radnih skupina projekta na nacionalnoj razini

- donošenje Pravilnika o uvjetima za izbor u znanstvena zvanja te, $\mathrm{s}$ tim u svezi, mjerenje znanstvene produktivnosti - pravilnikom su knjižnice dobile nove zadaće te se ukazala potreba za daljnjom edukacijom u području bibliometrijskih usluga

- poslovanje s elektroničkim izvorima (nabava baza UNIRI i nacionalne licence)

- primjena Zakona o zaštiti osobnih podataka u knjižnicama itd.

Unatrag pet godina, kako je vidljivo iz tablice 1, sveukupno je održano 35 radionica s 29 različitih tema te sedam skupova. Na godišnjoj razini, Sveučilišna knjižnica za stručno knjižničarsko osoblje SveRiKS-a najčešće planira šest sadržajno različitih radionica, a od toga broja izuzetno rijetko one namijenjene samo stručnom osoblju SVKRI-a. Godina 2014. izdvaja se ukupnim brojem održanih radionica jer je zbog potreba uzajamne katalogizacije radionica „Rad u Skupnom katalogu Crolist i Skupnom katalogu Sveučilišta u Rijeci“ održana sedam puta. U

20 Podaci preuzeti iz internih evidencija SVKRI-a o održanim programima stručnog usavršavanja za knjižničare SveRiKS-a, a koje SVKRI (su)organizira. 
navednom petogodišnjem razdoblju, prema evidencijama prisustva, na radionicama je sveukupno prisustvovalo 387, a na skupovima 125 knjižničara SveRiKS-a.

Tablica 1. Pregled broja programa stručnog usavršavanja i prisustva knjižničarskog osoblja SveRiKS-a na planiranim programima 2013.-2017. ${ }^{21}$

\begin{tabular}{|c|c|c|c|c|c|}
\hline \multirow{2}{*}{ Godina } & \multicolumn{4}{|c|}{ Programi stručnog usavršavanja za knjižničarsko osoblje SveRiKS-a } \\
\cline { 2 - 6 } & \multicolumn{2}{|c|}{ Broj realiziranih programa } & \multicolumn{2}{c|}{ Broj prisutnog stručnog osoblja } \\
\cline { 2 - 6 } & $\begin{array}{c}\text { Br. } \\
\text { radionica }\end{array}$ & $\begin{array}{c}\text { Br. } \\
\text { tema }\end{array}$ & $\begin{array}{c}\text { Br. skupova } \\
\text { i sl. }\end{array}$ & Na radionicama & $\begin{array}{c}\text { Na skupovima } \\
\text { i sl. }\end{array}$ \\
\hline 2013. & 6 & 6 & 2 & 66 & 28 \\
\hline 2014. & 12 & 6 & 2 & 90 & 48 \\
\hline 2015. & 6 & 6 & 1 & 90 & 14 \\
\hline 2016. & 6 & 6 & 1 & 90 & 20 \\
\hline 2017. & 5 & 5 & 1 & 51 & 15 \\
\hline
\end{tabular}

Osim godišnjih planiranih radionica za stručno knjižničarsko osoblje u sustavu SveRiKS, knjižničari se prema ponudama i potrebama uključuju i u sadržaje u organizaciji drugih ustanova. Sveučilišna knjižnica Rijeka nema podatke o broju i učestalosti uključivanja knjižničara fakultetskih knjižnica u druge oblike i sadržaje stručnog usavršavanja, ali redovito vodi evidenciju svih programa stručnog usavršavanja svojih djelatnika. Tako je u razdoblju od 2013. do 2017. knjižničarsko osoblje SVKRI-a bilo uključeno u 118 različitih programa stručnog usavršavanja (uključujući i one planirane za knjižničarsko osoblje SveRiKS-a), a ostalo osoblje u 45. Na razini Sveučilišne knjižnice Rijeka tijekom pet godina evidentirano je sveukupno 468 sudjelovanja u 144 različita sadržaja edukacija, ne uključujući sate programa dodatnog formalnog školovanja za stjecanje više razine obrazovanja pojedinih djelatnika.

Treba naglasiti da je cjeloživotno učenje i knjižničarskog i ostalog knjižničnog osoblja za Sveučilišnu knjižnicu Rijeka izuzetno važno. Praćenje promjena i trendova u okruženju te zahtjeva korisnika i osnivača usmjeravaju upravu i osoblje prema sadržajima edukacija koji doprinose kvaliteti poslovanja, vođenja i koordiniranja aktivnosti, bilo da se radi o SVKRI-u, SveRIKS-u ili ostalim knjižnicama u sustavu matičnosti.

21 Isto. 


\section{Istraživanje potreba i mogućnosti stručnog usavršavanja knjižni- čara u sustavu SveRiKS}

\subsection{Svrha, cilj i predmet istraživanja}

Imajući u vidu činjenicu da SVKRI redovito (su)organizira stručno usavršavanje knjižničara SveRiKS-a u svojim prostorima te činjenicu da isti knjižničari prisustvuju i ostalim edukacijama i skupovima koje redovito organiziraju razne institucije, društva, tijela i sl., pretpostavke su ovog istraživanja da knjižničari SveRiKS-a redovito sudjeluju u programima stalnog stručnog usavršavanja te da SVKRI kao (su)organizator programa stručnog usavršavanja prati i predviđa potrebe knjižničara u sustavu.

Svrha je istraživanja utvrditi stavove i mišljenja knjižničara o vlastitom stručnom usavršavanju unatrag pet godina, otkriti probleme u realizaciji sudjelovanja u programima, utvrditi područja/teme za koje postoji potreba organiziranja edukacija te najpoželjniji način prijenosa znanja.

Sveučilišna knjižnica Rijeka ovim je istraživanjem željela dobiti podatke koji bi bili polazište za daljna promišljanja u (su)organizaciji edukacija knjižničara SveRiKS-a.

Nastavno na svrhu, ciljevi istraživanja jesu:

utvrditi kako ispitanici procjenjuju zadovoljstvo svojom uključenošću u razne oblike stručnog usavršavanja u posljednjih pet godina

utvrditi imaju li ispitanici podršku nadređenih te razloge za nesudjelovanje u raznim oblicima stručnog usavršavanja, odnosno probleme kod odlazaka na skupove, organizirane edukacije i sl. u posljednih pet godina utvrditi potrebe knjižničara za dodatnom edukacijom te način na koji žele da ti sadržaji budu organizirani i/ili dostupni.

Predmet istraživanja jesu podaci iz internih evidencija SVKRI-a te informacije prikupljene anketnim ispitivanjem knjižničara SveRiKS-a, odnosno njihova procjena zadovoljstva vlastitim stručnim usavršavanjem unazad pet godina, razlozi neuključivanja te iskazane potrebe.

\subsection{Metodologija istraživanja}

\subsubsection{Uzorak i postupak}

Istraživanje je provedeno u rujnu 2018. godine putem anketnog upitnika (Pri$\log 1)$. Poziv na ispunjavanje, s poveznicom na online upitnik, upućen je e-poštom zaposlenicima knjižnica SveRiKS-a (ukupno 36 zaposlenika - 18 zaposlenika Sveučilišne knjižnice Rijeka, uključujući i Podružnicu, te 18 zaposlenika fakul- 
tetskih knjižnica). Upitnik je bio dostupan za ispunjavanje tijekom sedam dana uz osiguranu anonimnost prilikom ispunjavanja.

Kako bi se dobio što ujednačeniji uzorak, tj. kako bi se dobili podaci koji su istovrijedni i za sveučilišnu knjižnicu i za visokoškolske knjižnice koje djeluju u knjižničnom sustavu Sveučilišta u Rijeci, istraživano je samo stalno zaposleno knjižničarsko osoblje u knjižničnim zvanjima (pomoćni knjižničari, knjižničari, diplomirani knjižničari, viši knjižničari i knjižničarski savjetnici) koje radi na radnim mjestima stručnog osoblja ili je na položajnom radnom mjestu (npr. voditelji knjižnica, voditelji odjela i sl.) koje uključuje poslove knjižničarskog osoblja. Zbog toga je iz istraživanja isključen dio osoblja zaposlen u Sveučilišnoj knjižnici Rijeka koji unazad pet godina nije obavljao iste ili slične poslove i obnašao funkcije kao osoblje zaposleno u fakultetskim knjižnicama. Isključeno je sljedeće osoblje: ravnateljica SVKRI-a, osobe na radnim mjestima voditelja Službe za odnose s javnošću i Službe za primjenu IT-a u knjižnici, administrativno, tehničko i ostalo osoblje.

\subsubsection{Anketni upitnik}

Anketni upitnik (Prilog 1) izrađen je na Googleovu obrascu zbog jednostavnosti ispunjavanja, automatskog prikupljanja i obrade podataka. Prilikom kreiranja upitnika nisu predviđena pitanja kojima se može identificirati pojedini ispitanik. Također, prilikom zaprimanja ispunjenih upitnika onemogućen je prikaz bilo kakve informacije koja bi povrijedila anonimnost. Upitnik sadrži 12 pitanja - devet obveznih (od toga dva s mogućnošću višestrukog odgovora) i tri neobvezna, otvorenog tipa. Upitnik je koncipiran na način da se njime prikupe osnovni podaci, stavovi, mišljenja i potrebe ispitanika kako bi se dobila opća slika stanja o stručnom usavršavanju knjižničara na razini SveRiKS-a.

Nakon uvodnog dijela u kojem se ispitanicima objašnjava svrha prikupljanja podataka, prva tri pitanja odnose se na utvrđivanje činjenica kao što su godine staža ispitanika u knjižničarskoj struci, jesu li u posljednijih pet godina obnašali ili još uvijek obnašaju neku od voditeljskih funkcija te jesu li aktivno uključeni u rad pojedinih stručnih i/ili radnih tijela (npr. komisije Hrvatskoga knjižničarskog društva, radne skupine Dabra i sl.). Nakon toga slijedi procjena u kojoj se mjeri njihovo područje profesionalnog interesa podudara s poslovima koje obavljaju.

Zatim slijede pitanja o procjeni vlastitog zadovoljstva uključenošću u organizirane sadržaje stručnog usavršavanja te koliko nadređeni ili uprave podržavaju odlazak na edukacije, stručne skupove i sl. Pitanja s mogućnošću višestrukog odgovora - razlozi zbog kojih u posljednjih pet godina nisu prisustvovali stručnoj edukaciji, skupu ili sl. te najpoželjniji načini prijenosa znanja prilikom stručnog usavršavanja - trebaju stvoriti polazište za promišljanje kako (su)organizirati edukacije u narednom razdoblju. Pitanjem o procjeni raspoloživosti dostatne stručne pomoći za konkretne poslove na radnom mjestu, na razini knjižnice, odnosno Sve- 
RiKS-a, želi se utvrditi procjenjuju li ispitanici svoje kolege u sustavu dovoljno stručnima da mogu od njih zatražiti i dobiti stručnu pomoć.

Posljednja tri pitanja neobvezna su za ispitanike, ali su važna radi utvrđivanja njihovih potreba i interesa. Ponuđena im je mogućnost da navedu konkretne poslove i aktivnosti za koje bi im koristila dodatna edukacija te teme predavanja ili radionica koje bi željeli poslušati, s obzirom na to da se područja njihova profesionalnog interesa ne moraju nužno podudarati s poslovima koje obavljaju. Posljednjim pitanjem omogućeno je da se autoricama ankete dostavi bilo kakva poruka ili napomena.

\subsection{Rezultati istraživanja}

Anketnom ispitivanju odazvalo se 26 knjižničara, odnosno $72,2 \%$, što je odaziv koji omogućava donošenje zaključaka koji se tiču svega knjižničarskog osoblja u sustavu SveRiKS. Devetnaest (73 \%) ispitanika ima više od deset godina radnog staža u knjižničarskoj struci (jedan ispitanik do 5 g., šest ispitanika 6-10 g., devet ispitanika 11-20 g., sedam ispitanika 21-30 g., tri ispitanika iznad 31 g.) i usvojene temeljne kompetencije za obavljanje poslova na radnom mjestu, a pretpostavka je da mogu i objektivno procijeniti svoje potrebe za stručnim usavršavanjem u odnosu na vlastite profesionalne interese, poslove koje obavljaju i zahtjeve okoline.

U posljednjih pet godina 12 ispitanika radilo je ili još radi kao voditelj (knjižnice/odjela i sl.), a od toga broja osam ih je i aktivno uključeno ili je bilo uključeno u rad stručnih/radnih tijela, uz još šest drugih ispitanika. Sudjelovanje u anketi za ovih je 18 (69,2 \%) ispitanika važno s obzirom na to da se radi o osobama koje upravljaju poslovanjem ili su aktivni pokretači i izvršitelji promjena. Ipak, ne ulazeći u dublje analize, pregledom odgovora na pitanja iz upitnika postaje vidljivo da njihovi odgovori nemaju značajnija odstupanja u odnosu na preostalih osam ispitanika.

Od ukupnog broja ispitanika, za njih se 6 područja njihova profesionalnog interesa u potpunosti podudaraju s poslovima koje obavljaju, a za 12 uglavnom, dok se kod 7 djelomično podudaraju, a samo se kod jedne osobe ne podudaraju. Rezultati upućuju na zaključak da je većina njih (69,3\%) zadovoljna na svojim radnim mjestima te da dobro prepoznaje svoje potrebe za stručnim usavršavanjem kojim unapređuje poslove na kojima radi.

Slika 1 prikazuje kako su ispitanici, na skali procjene od 1 (nisam zadovoljna/ zadovoljan) do 5 (u potpunosti sam zadovoljna/zadovoljan), procijenili vlastito zadovoljstvo svojom uključenošću u organizirane sadržaje stručnog usavršavanja u posljednjih pet godina. 


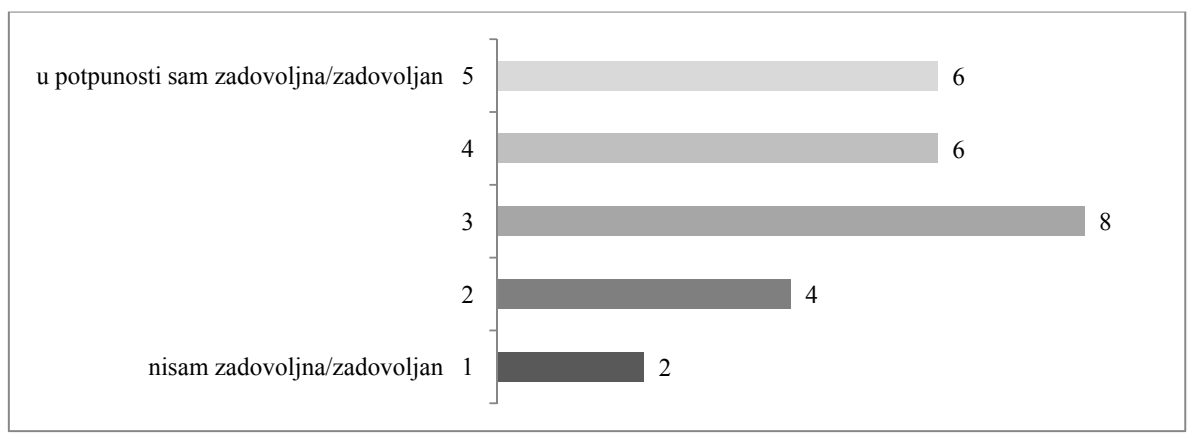

Slika 1. Procjena zadovoljstva uključenošću u organizirane sadržaje stručnog usavršavanja u posljednjih pet godina

Iako je $12(46,2 \%)$ ispitanika zadovoljno osobnim uključivanjem u organizirane edukacije u proteklih pet godina, osam (30,8 \%) prosječno zadovoljnih te šest $(23,1 \%)$ uglavnom nezadovoljnih ispitanika pokazatelj su da na razini SveRiKS-a treba promišljati načine i teme edukacija kojima bi se uključilo sve knjižničarsko osoblje.

Većina, odnosno 20 (76,9\%) ispitanika smatra da ih kod odlazaka na edukacije, stručne skupove i sl. nadređeni i uprave potpuno ili uglavnom podržavaju, što je vidljivo iz slike 2. Manji dio ispitanika ne osjeća tu podršku, odnosno četvero smatra da ih nadređeni samo djelomično podržavaju, a dvoje da tu podršku uopće nemaju.

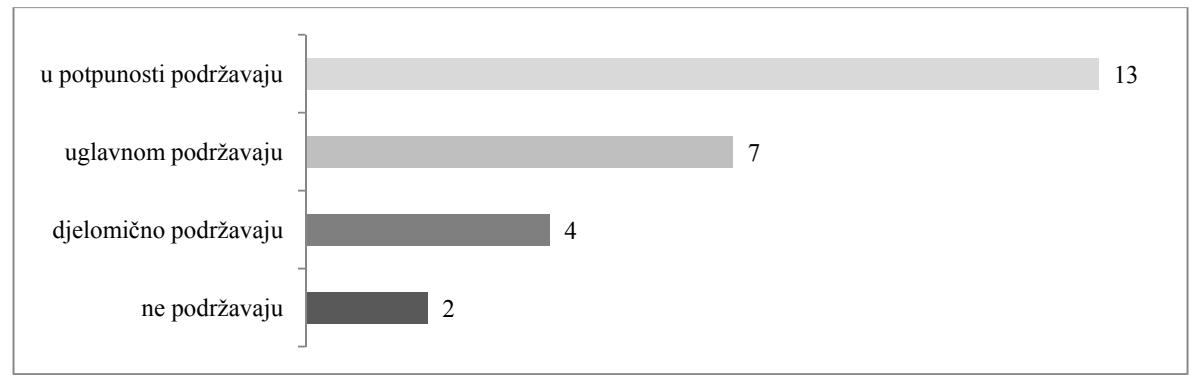

Slika 2. Podrška nadređenih/uprave kod odlazaka na edukacije, stručne skupove i sl.

Osnovnim razlogom neuključivanja u razne oblike stručnog usavršavanja u posljednjih pet godina $13(50,0 \%)$ od 26 ispitanika smatra to što teme edukacija nisu izravno primjenjive na poslove koje obavljaju, a deset (38,5\%) od 26 smatra da se radi o organizacijskim problemima poslovanja u vrijeme odsustva s radnog mjesta. Broj odabira ostalih razloga vidljiv je na slici 3. 


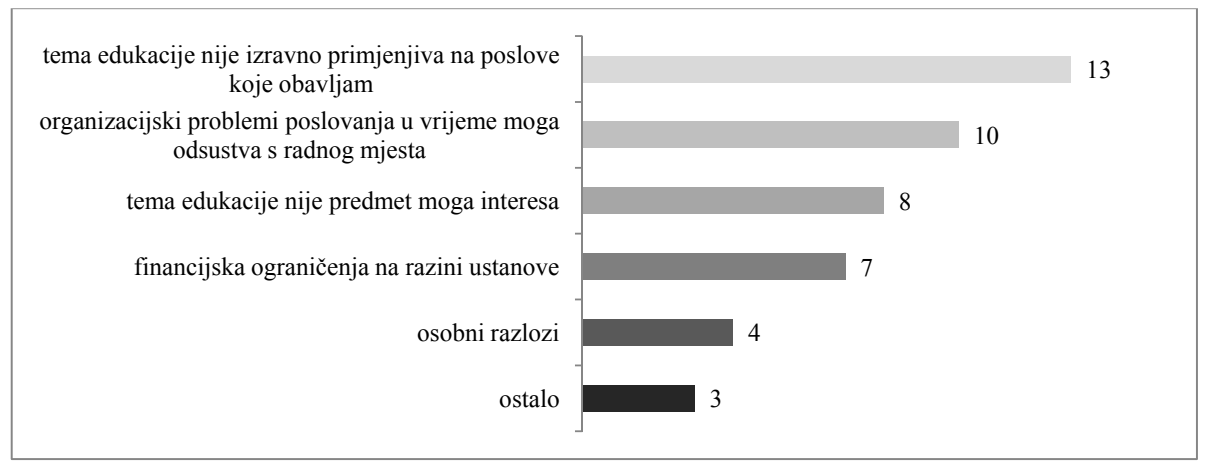

Slika 3. Najčešći razlozi neuključivanja u razne oblike stručnog usavršavanja u posljednjih pet godina

Kod procjene raspoloživosti dostatne stručne pomoći u vlastitoj knjižnici ili sustavu SveRiKS 20 ispitanika (76,9 \%) smatra da ju ima, pet ispitanika (19,2 \%) ima mišljenje da im je takva pomoć uglavnom na raspolaganju, a samo jedna osoba procjenjuje da takve pomoći nema.

Najpoželjniji način prijenosa znanja za 23 (88,5 \%) su ispitanika vođene radionice, zatim slijede predavanja i tribine te online materijali, što je prikazano na slici 4.



Slika 4. Poželjni načini prijenosa znanja

U posljednja tri neobvezna pitanja otvorenog tipa $13(50,0 \%)$ ispitanika navelo je poslove i aktivnosti za koje bi im koristila dodatna edukacija, 12 (46,1\%) ih je navelo koje bi teme predavanja ili radionica željeli poslušati, a dvoje ispitanika napisalo je i poruku/napomenu. Kako se kod većine ispitanika područje poslova koje obavljaju podudara s područjem njihova profesionalnog interesa, odgovori na pitanja ,Za koje bi Vam konkretne poslove ili aktivnosti koristila dodatna edu- 
kacija?“ i „Koja biste predavanja ili radionice željeli poslušati? Navedite teme.“ bili su uglavnom isti te su pisani najčešće kao natuknice (npr. bibliometrija, komunikacijske vještine, razvoj korisničkih servisa itd.). Dvoje ispitanika u zadnjem je pitanju dodatno iskazalo svoje mišljenje naglašavajući važnost uloge voditelja, usavršavanja pregovaračkih i prezentacijskih vještina za bolje pozicioniranje unutar institucije, ujednačenog pristupa bibliometrijskim analizama, usustavljene informiranosti knjižnica u sastavu, razmjene iskustava i međusobne komunikacije.

Iskazane potrebe za edukacijom raspoređene su prema temama u šest okvirnih grupa koje su ovdje prikazane redoslijedom ovisnim o broju i učestalosti pojavljivanja pojedinih prijedloga:

- knjižnične službe i usluge (komunikacijske vještine, prezentacijske vještine, znanstvena komunikacija, pedagoške kompetencije, informacijska pismenost, zaštita građe, interdisciplinarne teme)

- informacijski alati / knjižnični softver (razvoj korisničkih servisa i informacijskih alata, priprema interaktivnih radionica, alati za e-učenje, rad u Crolistu, rad u SharePointu)

- upravljanje i javno zagovaranje (aktivnosti radi boljeg pozicioniranja i vidljivosti knjižnice, zagovaranje knjižnice, učinkovito pregovaranje, upravljanje, strateški i krizni menadžment, online marketing)

- vrednovanje i istraživanje (vrednovanje znanstvene produkcije, bibliometrija, primjena statističkih metoda i alata, sustav kvalitete)

- elektronički informacijski izvori (nabava e-izvora, pretraživanje e-izvora, baze podataka)

- formalna i sadržajna obrada (UDK, predmetna obrada, katalogizacija časopisa).

Vidljivo je da knjižničari u sustavu na prvo mjesto stavljaju edukacije u vještinama koje uobičajeno nisu obuhvaćene sustavom formalnog obrazovanja knjižničara (komunikacija, prezentacija, pedagoške kompetencije itd.). Također, teme koje smatraju važnima prate aktualnosti u okruženju u kojem knjižničari svakodnevno djeluju.

\subsection{Zaključci istraživanja}

Ovom anketom utvrđeno je da su knjižničari SveRiKS-a uglavnom zadovoljni time koliko su se uključivali u razne organizirane sadržaje stručnog usavršavanja u posljednjih pet godina (2013.-2017.), ali i da treba pronaći način za povećanje broja uključivanja, kao i za uključivanje svega knjižničarskog osoblja.

Odlazak na skupove, organizirane edukacije i sl. u većini je slučajeva podržan od izravno nadređenih osoba u knjižnici, dekana fakulteta ili ravnateljice SV- 
KRI-a, ali se često ne može realizirati zbog organizacijskih problema poslovanja na samom radnom mjestu. Knjižničari stoga pažljivo biraju edukacije na kojima će prisustvovati i teme koje su izravno primjenjive na poslove koje obavljaju, a tek onda one koje su predmet njihova interesa. Stručno osoblje SveRiKS-a, prvenstveno iz Sveučilišne knjižnice Rijeka koja obavlja matičnu djelatnost za knjižnice u sastavu Sveučilišta, ali i iz fakultetskih knjižnica, svojim profesionalnim interesima i znanjima može pružati stručnu pomoć svojim kolegama u sustavu. Ipak, za složenije edukacije i prijenos novih znanja Sveučilišna knjižnica Rijeka (su) organizira edukacije za knjižničare u sustavu, a koje za pojedina područja nude i razni stručnjaci iz drugih knjižnica, ustanova, centara, društava i sl.

Prema rezultatima ove ankete, u daljnjem planiranju stručnog usavršavanja knjižničara u sustavu treba imati na umu i to da gotovo svi knjižničari vođene radionice smatraju najpoželjnijim načinom prijenosa znanja. Knjižničari u sustavu ukazuju na potrebu usavršavanja komunikacijskih, prezentacijskih, informacijskih, informatičkih, pedagoških i drugih vještina koje ne pripadaju u temeljne knjižničarske kompetencije u formalnom sustavu obrazovanja, a sistemsko knjižničarstvo pokazuje se kao nužnost. Voditelji također iskazuju i specifične potrebe vezane uz svoja radna mjesta te predlažu i teme budućih edukacija koje se odnose na upravljanje, zagovaranje, pregovaranje i bolju vidljivost knjižnica i/ili knjižničnih usluga. Uz navedeno, potrebno je i učvrstiti znanja i postupke za aktualne poslove i usluge koje knjižnica pruža, posebno one vezane uz sustave kvalitete, bibliometrijske usluge i vrednovanja znanstvene produkcije znanstveno-nastavnog osoblja, a u svrhu ujednačenosti kvalitete pružanja tih usluga na razini knjižničnog sustava Sveučilišta u Rijeci.

\section{Zaključak}

Sveučilišna knjižnica Rijeka redovito prati izazove okruženja te u skladu s tim redovito organizira ili suorganizira edukacije za knjižničarsko osoblje u sustavu SveRiKS. Analiza održanih radionica unatrag pet godina (2013.-2017.) pokazuje da su teme birane u skladu s potrebama knjižničara i zahtjevima okoline, a u svrhu učinkovitijeg i kvalitetnijeg poslovanja u knjižnici i sustavu. Rezultati istraživanja mogu poslužiti Sveučilišnoj knjižnici i za pregovore s osnivačem kako bi se na razini Sveučilišta u Rijeci usustavilo organiziranje edukacija za sve knjižnično osoblje.

Rezultati ankete pokazuju da se knjižničarsko osoblje kontinuirano stručno usavršava te da nisu više samo nužni edukacijski sadržaji vezani uz temeljne knjižničarske poslove. Stanje u sustavu pokazuje potrebu knjižničara za usavršavanjem postojećih znanja, ali i, što je još važnije, za stjecanjem novih znanja i kompetencija u skladu s promjenama u okruženju. Kako je SveRiKS relativno malen sustav, zajednica knjižničarskog osoblja dobro se poznaje te može kvalitet- 
no međusobno razmjenjivati iskustva i znanja. Usprkos razvoju tehnologije i mogućnostima koje ona pruža u komunikaciji te dostupnosti i prijenosu informacija i znanja na daljinu, susreti kroz radionice, predavanja i tribine za knjižničare su i dalje najpoželjniji načini stjecanja novih znanja ili razmjene iskustava.

Problem predstavljaju izostanci s radnog mjesta, bilo zbog sastanaka, odlazaka na skupove ili stručne edukacije, pa je zbog toga poželjno da Sveučilišna knjižnica Rijeka što više programa stručnog usavršavanja za knjižničare SveRiKS-a organizira u svojim prostorima ili na području Rijeke i okolice. Izazov koji se pred Sveučilišnu knjižnicu Rijeka postavlja u narednom razdoblju jest osmišljavanje plana stručnog usavršavanja za knjižničare SveRiKS-a, uvažavajući rezultate ankete. Autorice smatraju da bi se za ujednačavanje poslovanja u pojednim segmentima poslovanja, posebno kod pružanja pojedinih usluga u knjižničnom sustavu Sveučilišta u Rijeci, radionice većim dijelom mogle organizirati sa stručnim knjižničarskim osobljem u sustavu ili sa stručnjacima Sveučilišta u Rijeci. Rezultati ispitivanja pokazuju da treba organizirati vođene radionice na kojima bi se obradili konkretni sadržaji koji se odmah mogu primijeniti na aktualne poslove. Potrebno je organizirati veći broj kraćih radionica s dostupnim online materijalima (upute, postupci i sl.), a neke od njih i više puta, kako bi se uključilo sve knjižničarsko osoblje, posebno ono iz fakultetskih knjižnica. Naravno, za složenije i nove stručne teme te one za koje knjižničari pokažu zainteresiranost i nadalje treba u suorganizaciji s drugim knjižnicama, centrima, društvima, ustanovama i sl. pozivati stručnjake da održe radionice ili predavanja u prostorima SVKRI-a.

Rezultati ispitivanja pokazali su da veći broj knjižničara obavlja poslove za koje je i profesionalno zainteresiran, pa se $\mathrm{i}$ iskazane potrebe za dodatnom edukacijom radi zadovoljavanja potreba samoga posla i profesionalnih interesa preklapaju. Knjižničari su najviše zainteresirani za teme koje će doprinijeti razvoju njihovih komunikacijskih, prezentacijskih, informacijskih, informatičkih, pedagoških, organizacijskih, upravljačkih, pregovaračkih i drugih vještina te znanja iz područja sistemskog knjižničarstva. Temeljne kompetencije više nisu dovoljne, već se kontinuirano trebaju usvajati specifična znanja i vještine, u skladu s potrebama korisnika i promjenama u okruženju.

\section{LITERATURA}

Aparac-Jelušić, T. Obrazovanje za digitalne knjižnice: pogled iz Europe. // Libellarium 9, 2(2016), 5-24. [citirano 2018-10-5]. Dostupno na: https://hrcak.srce.hr/index. php?show=clanak\&id_clanak_jezik=260470. 
Erl Šafar, M.; T. Lubina. Formalno obrazovanje knjižničara : kratki povijesni pregled. // Vjesnik bibliotekara Hrvatske 61, 1(2018), 219-239. DOI: https://doi.org/10.30754/ vbh.61.1.647.

Horvat, A. Cjeloživotno učenje knjižničara u Hrvatskoj: stanje i mogućnosti. // Cjeloživotno učenje knjižničara: ishodi učenja i fleksibilnost / urednice Aleksandra Horvat, Dijana Machala. Zagreb: Nacionalna i sveučilišna knjižnica, 2009. [citirano: 201810-31]. Dostupno na: http://www.nsk.hr/cuk/cuk.pdf.

Hrvatsko knjižničarsko društvo. Skupovi u zemlji. Arhiva. [citirano 2018-11-27]. Dostupno na: http://hkdrustvo.hr/hr/skupovi/arhiva/u_zemlji/.

Ivančić Medved, I. Knjižničar i karijera. // Knjižničarstvo 17, 2(2013), 75-84. [citirano 2018-10-4]. Dostupno na: http://www.knjiznicarstvo.com.hr/2014/05/08/228-ivancic-medved/.

Lazzarich, L. Kontinuirana edukacija informacijskih stručnjaka (ili možete li dobiti posao). // Edukacija korisnika i knjižničnog osoblja / 5. dani specijalnog knjižničarstva Hrvatske, Opatija, 10. i 11. travnja 2003. Zagreb: Hrvatsko knjižničarsko društvo, 2004. Str. 56-64.

Machala, D. Knjižničarske kompetencije: pogled na razvoj profesije. Zagreb: Hrvatska sveučilišna naklada: Nacionalna i sveučilišna knjižnica, 2015.

Machala, D.; A. Horvat. Nacionalni program trajne izobrazbe knjižničara temeljen na ishodima učenja: prema priznavanju neformalnog obrazovanja knjižničara. // Cjeloživotno učenje knjižničara: ishodi učenja i fleksibilnost / urednice Aleksandra Horvat, Dijana Machala. Zagreb: Nacionalna i sveučilišna knjižnica, 2009. Str. 151-162. [citirano: 2018-10-31]. Dostupno na: http://www.nsk.hr/cuk/cuk.pdf.

Strategija Sveučilišta u Rijeci 2007.-2013. [citirano: 2018-10-29]. Dostupno na: http:// www.uniri.hr/files/staticki_dio/strategija/SVURI01-01Strategija.pdf.

Sveučilišna knjižnica Rijeka. Knjižnični sustav sveučilišta u Rijeci. [citirano 201810-5]. Dostupno na: https://svkri.uniri.hr/index.php/knjiznicni-sustav-sveucilista/ knjiznice.

Sveučilišna knjižnica Rijeka. Knjižnični sustav sveučilišta. [citirano 2018-10-5]. Dostupno na: https://svkri.uniri.hr/index.php/knjiznicni-sustav-sveucilista/o-sustavu.

Sveučilišna knjižnica Rijeka. O nama. [citirano 2018-10-5]. Dostupno na: https://svkri. uniri.hr/index.php/o-nama/djelatnici.

Švenda-Radeljak, K. Obrazovanje i status knjižničara u Hrvatskoj do uvođenja studija bibliotekarstva. Zagreb: Pravni fakultet Sveučilišta, 2018.

Transforming our world: the 2030 agenda for sustainable development. [citirano 201810-30]. Dostupno na: https://sustainabledevelopment.un.org/post2015/transformingourworld. 


\section{PRILOZI}

\section{Prilog 1. Anketni upitnik „Stručno usavršavanje knjižničara knjižnič- nog sustava Sveučilišta u Rijeci““}

\section{*Obvezan odgovor}

1. Koliko godina staža imate u knjižničarskoj struci? *

do 5 godina

6-10 godina

11-20 godina

21-30 godina

31 godina i više

To je obavezno pitanje

2. Jeste li u posljednih pet godina obnašali ili još uvijek obnašate neku od voditeljskih funkcija u knjižnici (npr. voditelj/ica knjižnice, voditelj/ica odjela/odsjeka/ službi i sl.)? *

\section{DA}

NE

To je obavezno pitanje

3. Jeste li u posljednjih pet godina bili ili ste još uvijek aktivno uključeni u rad pojedinih stručnih i/ili radnih tijela (npr. komisije HKD-a, radne skupine Dabar itd.) ${ }^{*}$

\section{DA}

$\mathrm{NE}$

To je obavezno pitanje

4. U kojoj se mjeri područje Vašeg profesionalnog interesa podudara s poslovima koje obavljate? *

potpuno se podudara

uglavnom se podudara

$\square$ djelomično se podudara

$\square \quad$ ne podudara se

To je obavezno pitanje 
To je obavezno pitanje

5. Koliko ste zadovoljni svojom uključenošću u organizirane sadržaje stručnog usavršavanja u proteklih pet godina? *

$\begin{array}{lllllll}\text { nisam } & 1 & 2 & 3 & 4 & 5 & \text { u potpunosti sam } \\ \text { zadovoljna/zadovoljan } & 0 & 0 & 0 & 0 & 0 & \text { zadovoljna/zadovoljan }\end{array}$

6. Podržavaju li nadređeni i uprava Vaš odlazak na edukacije, stručne skupove i slično? *

u potpunosti podržavaju

uglavnom podržavaju

$\square \quad$ djelomično podržavaju

$\square$ ne podržavaju

To je obavezno pitanje

7. Koji su najčešći razlozi zbog kojih u posljednjih pet godina niste prisustvovali stručnoj edukaciji, skupu i slično? (moguće je više odgovora) *

tema edukacije nije predmet moga interesa

tema edukacije nije izravno primjenjiva na poslove koje obavljam

organizacijski problemi poslovanja u vrijeme moga odsustva s radnog mjesta

financijska ograničenja na razini ustanove

osobni razlozi

ostalo:

To je obavezno pitanje

8. Smatrate li da za konkretne poslove na Vašem radnom mjestu imate na raspolaganju dostatnu stručnu pomoć na razini Vaše knjižnice/SveRiKS-a? *

nemam

uglavnom imam

imam

To je obavezno pitanje

9. Koji Vam način prijenosa znanja kod stručnog usavršavanja najviše odgovara? (moguće je više odgovora) *

mentorstvo

vođene radionice

predavanje, tribine 
webinari u realnom vremenu s mogućnošću interakcije s voditeljem i sudionicima

snimke webinara

online materijali

ostalo:

To je obavezno pitanje

10. Za koje bi Vam konkretne poslove ili aktivnosti koristila dodatna edukacija?

To je obavezno pitanje

11. Koja biste predavanja ili radionice željeli poslušati? Navedite teme:

To je obavezno pitanje

12. Ako imate poruku ili napomenu, molimo da ju napišete: 